\title{
Fertility, Agricultural Labor Supply, and Production: Instrumental Variable Evidence from Uganda
}

\section{Bjorn Van Campenhout}

\begin{abstract}
Human fertility can affect agricultural production through its effect on supply of agricultural labor. Using the fact that in traditional, patriarchal societies, sons are generally preferred to daughters, we isolate exogenous variation in the number of children born to a mother and relate it to the agricultural labor supply and production in Uganda, which has a dominant agricultural sector and high fertility. We find that fertility has a sizable negative effect on household labor allocation to subsistence agriculture. Households with lower fertility devote significantly more time to land preparation and weeding; larger households grow less matooke and sweet potatoes. We find no significant effect on agricultural productivity in terms of yield per land area.
\end{abstract}

Key Words: fertility, instrumental variables, labor supply, Uganda

At the most basic level, subsistence farmers in rural Africa combine natural resources with human resources to make a living. They use mainly household labor on their own small plots to produce food for their consumption. Therefore, their household allocations of total available time to various activities has an important effect on the agricultural labor supply, production patterns, productivity, and, ultimately well-being. In households in which there are a large number of children, domestic and reproductive labor compete with agricultural labor, and mothers especially must allocate a greater amount of time to caring for children. Since women supply a substantial amount of the agricultural labor in rural Uganda (Ali et al. 2015), their time spent caring for children and additional rest needed during pregnancy are likely to have a disproportionately negative impact on agricultural households that is quite different from the impacts of other reductions of a household's labor supply, such as illness of a male member.

\footnotetext{
Bjorn Van Campenhout is a research fellow with the International Food Policy Research Institute and an associated senior researcher with the LICOS Centre for Institutions and Economic Performance at the KULeuven in Belgium. Correspondence: Bjorn Van Campenhout International Food Policy Research Institute - Waaistraat 6 - bus 3511 - B-3000 Leuven - Belgium - Phone +32.488.147073 - Email b.vancampenhout@cgiar.org.

The views expressed are the authors' and do not necessarily represent the policies or views of any sponsoring agencies.
}

Agricultural and Resource Economics Review 45/3 (December 2016) 581-607

(C) The Author(s) 2016. This is an Open Access article, distributed under the terms of the Creative Commons Attribution-NonCommercial-ShareAlike licence (http://creativecommons.org/licenses/ by-nc-sa/4.0/), which permits non-commercial re-use, distribution, and reproduction in any medium, provided the same Creative Commons licence is included and the original work is properly cited. The written permission of Cambridge University Press must be obtained for 
Fertility rates in Uganda remain among the highest in the world even in the context of large reductions in child mortality. On average, Ugandan women in rural areas bear 6.8 children over the course of their reproductive lives (Uganda Bureau of Statistics (UBOS) 2014). At the same time, a substantial part of the population lives in rural areas and makes a living from semisubsistence agriculture. Uganda's agriculture sector employs about 72 percent of the active labor force (UBOS 2014). Virtually all households in rural areas engage in farming, and the vast majority are small-scale, semisubsistence farmers. Consequently, the question of how fertility affects wellbeing through its impact on household labor supplies and agricultural production is important.

In this study, we investigate the effect of fertility on the division of labor and agricultural production at the household level using data from a household survey conducted in Uganda. In particular, we investigate the effect of the number of biological children on households' member labor input in agriculture, which we further categorize as land preparation, weeding, input application, and harvesting. We also look at the effect of fertility on crop portfolios, area cultivated, production, and productivity for the nation's five most important crops-maize, beans, sweet potatoes, cassavas, and matookes, a starchy cooking banana. Fertility is a choice variable for agricultural households. For instance, mothers who work long hours in the field may try to avoid becoming pregnant because it would only increase their hardship. If fertility, agricultural labor allocations, and agricultural production are jointly determined, one must find a way to separate exogenous variation from variation that is jointly determined to uncover the true causal effect of fertility on the outcome variables. We use the fact that conservative, patriarchal societies such as Uganda's generally prefer male off-spring to female off-spring, resulting in particular fertility patterns (e.g., if the first three children born are girls, the family will continue to have children in hope of having boys whereas they might stop having children if the first three are boys). The random nature of a newborn's sex means that we can use reproductive patterns as an instrumental variable to determine the exogenous component of variations in fertility at the household level (Angrist and Krueger 2001).

We find that the sex of the first child born, the sex of the first two children born, and the percentage of a mother's children who are girls significantly explain observed fertility, which is measured as the difference between the actual number of children born to a woman and a theoretical maximal fecundity for each age cohort; high levels of fertility are represented by small differences. We further find that greater fertility has a strong negative effect on the number of days the mother works in the field. There is evidence of a negative effect on the father as well, but the size of that effect is half of that on the mother. Households with relatively low fertility devote significantly more time than other households to land preparation and weeding. Relatively small households produce the most matooke and sweet potatoes. We find no impact of fertility on yields. 


\section{Related Studies}

Fertility and the related concept of household size affect household well-being through consumption and production. Lanjouw and Ravallion (1995) focused on the effects of household size on consumption in a developing country. Their results contradicted the widely held view that larger households were usually relatively poor (due to increased competition for food) and that economies of scale in consumption had little offsetting effect. When they accounted for economies of scale in households, the negative correlation between household size and consumption expenditures disappeared. On the production side of farm households, the effect of household size is equally ambiguous. Larger households theoretically have a greater supply of labor that is not subject to the effects of moral hazard often attributed to hired labor. ${ }^{1}$ At the same time, though, a larger number of dependents in a household means that more time must be allocated to caring for them. Also, agricultural labor could be subject to diminishing returns.

The relationship between fertility and the supply of household labor has been studied most carefully in the field of labor economics in developed countries. Since this literature is so extensive, we mention only two of the most influential works here. The first is Angrist and Evans (1998), which attempted to quantify the effect of fertility on labor supply in the United States. That study dealt with the endogeneity of the number of a woman's children by exploiting the American preference for having both boys and girls (Williamson 1976), arguing that parents of same-sex siblings were more likely to have an additional child. They also found a larger number of children in a household reduced the mother's participation in the labor force but that effect was less pronounced than found in previous studies. They found that fertility had no effect on the labor force participation by fathers.

In the second study, Rosenzweig and Wolpin (1980a), exogenous variation in the number of children was obtained using the occurrence of twins as a woman's first-born as an instrument. The authors argued that comparing women whose first child was a singleton to women whose first children were twins allowed them to identify the causal effect of an extra child on an outcome (labor supply in their case). Since the occurrence of twins was exogenous, there was no danger that heterogeneity in women's preferences influenced the estimated coefficients. They found that household size only temporarily reduced the supply of female labor. ${ }^{2}$

\footnotetext{
1 For instance, Feder (1985) argued that moral hazard could be behind results showing that small farms were more efficient than large farms.

2 Becker (1960) and Becker and Lewis (1973) tested quantity-quality fertility models and a number of studies have used twins (Rosenzweig and Wolpin 1980b, Black, Devereux, and Salvanes 2005) and/or sibling sex composition (Conley 2000, Angrist, Lavy, and Schlosser 2010) as instruments.
} 
In the context of developing countries, Gupta and Dubey (2006) used the sex of the first two children as a natural experiment and found that poverty increased with household size in India. They made essentially the same argument we make, but their measure of welfare and the related concept of poverty relied on consumption per capita, which, as the independent variable, is likely to be problematic in a two-stage least-squares setting. There is a real possibility that the instrumental variable will affect the outcome variable directly rather than only through its influence on family size. For instance, if boys consume more food on average than girls, the exclusion restriction would be violated. Further evidence comes from Indonesia, where Kim et al. (2009) found that consumption decreased with an additional child. Kim and Aassve (2006) related fertility to the allocation of labor in households but moved away from the direct instrumental variable approach that is standard and instead estimated a reproduction function that took endogenous contraceptive choices into account. ${ }^{3}$

We are aware of no studies that have looked directly at the effect of fertility on agricultural labor and production decisions. However, since the bulk of the work related to bearing and rearing children falls to the women in a household, fertility is directly related to gender, and we can gain additional insights from the large body of literature on gender and agriculture. There is a welldocumented gap of 20-30 percent in productivity between plots owned or managed by men versus those owned or managed by women (Udry 1996, Food and Agriculture Organization 2011), and a number of studies have explored the reasons for it. Some studies (Agarwal 1994, Lastarria-Cornhiel 1997, Deere and Leon 2003) have found evidence that the lower productivity of plots managed by women can be partly explained by limits on their property rights. Several studies (Peterman, Behrman, and Quisumbing 2014, Chen, Bhagowalia, and Shively 2011) have attributed the gap to differences in non-land inputs and access to technology and services. In addition, women may generally have different priorities that influence their land allocations and crop mixes (Doss 2002), and the sexual division of labor in agriculture means that labor by men and women cannot be regarded as perfect substitutes (Jacoby 1991).

\footnotetext{
3 These studies used data from Asia, where gender at birth is already skewed in many countries. For instance, Gupta and Dubey (2006) drew their sample from India, which is particularly known for selective abortion of girls (Jha et al. 2011). This nonrandom distribution of the sex of the children born opens the door to potential correlation between the instrument and the error term of the structural equation. For example, less educated, relatively poor households that depend heavily on agriculture more often abort female fetuses (Jha et al. 2011). In the context of weak instruments, such correlation can seriously bias the resulting estimates (Bound, Jaeger, and Baker 1995). In Uganda, while there is a preference for boys, the normal reproduction rate is high and the cost of raising children is low so selective abortion is much less likely to be a concern.
} 
Peterman et al. (2011) in a study in Uganda found persistently lower productivity for plots managed by women and for female-headed households. Ali et al. (2015) used panel data from Uganda and a Oaxaca decomposition and found that lower productivity on female-managed plots could be attributed to the fact that women used less fertilizer and chemicals and fewer improved seeds. Another important determinant of the productivity gap identified by the study was that women less often cultivated cash crops such as bananas and coffee. Still, about 30 percent of the productivity gap remained unexplained. Ultimately, the authors were able to attribute twofifths of the productivity gap to women's greater childcare responsibilities, leading them to propose low-cost approaches such as community-based childcare to ease those constraints. Similar results were found by Kilic, Palacios-López, and Goldstein (2015) in a study conducted in Malawi.

\section{Preferences for Boys and Fertility}

There is considerable evidence that parents prefer boys to girls in many developing countries. ${ }^{4}$ Numerous studies have looked at correlations between a child's sex and variables related to well-being and health and found significant differences in outcomes attributed to sex bias. Das Gupta (1987) and Sen (1990) looked at high rates of mortality among female infants in India and Chen, Huq, and D'Souza (1981) and Pande (2003) investigated differential access to health care for boys and girls in Bangladesh and India respectively. Behrman (1988) and Hazarika (2000) found correlations between sex and nutrition and Behrman, Pollak, and Taubman (1982), Davies and Zhang (1995), and Alderman and King (1998) all found correlations between children's gender and the education they received.

Such preferences for boys have also been directly expressed by parents in surveys. Those preferences lead to decision rules associated with fertility in which the likelihood that a household will add more children is positively correlated to the number of surviving girls in the household. Jayachandran and Kuziemko (2011) referred to such decision rules as the "stop after a son" fertility pattern. Many studies have shown empirically that parents who have just had a son are more likely than parents who just had a daughter to stop having children (Das 1987) or to wait longer to have another child (Trussell et al. 1985, Arnold, Choe, and Roy 1998, Clark 2000, Drèze and Murthi 2001).

Jayachandran and Kuziemko (2011) argued that a preference for sons led mothers to breastfeed daughters for a relatively short time. Since breastfeeding is an effective form of birth control, this observed behavior

\footnotetext{
4 In developed countries, there is a preference for children of both sexes, as shown in Angrist and Evans (1998). In countries and cultures that exhibit a preference for boys, the sex balance in households is thus unlikely to be a valid instrument. This is exactly what van der Stoep (2008) found for South Africa.
} 
could explain why parents of sons seemed to wait longer before having another child. This consequence of sex bias also may partly explain a range of observed outcomes in terms of health and mortality and possibly even educational attainment. The authors' model showed that disparities could arise passively because of fertility preferences even when parents wanted boys and girls to have equal health and education. The "try until you have a boy" fertility rule results in girls having more siblings on average, which leads to greater competition for resources in the household.

A preference for boys has been explained by various cultural and economic factors documented in anthropological and demographic studies. In countries in which there is no formal, risk-free insurance in old age (such as pensions), parents may choose to invest more in the children who are more likely to be able to support them in old age (Behrman, Pollak, and Taubman 1982). The anthropological and demographic evidence emphasizes the dominant role of males in traditional patrimonial societies in which descent and inheritance are transmitted through the male line. Furthermore, male children strengthen the relationship between a wife and her husband's kin by guaranteeing continuation of his lineage and secure the wife's access to an inheritance and a place to live upon her husband's death. Older women obtain power through their sons and rule over their daughters-in-law (Kandiyoti 1988). In addition, the spread of primary schooling in sub-Saharan Africa has affected fertility patterns (Lloyd, Kaufman, and Hewett 2000). Because boys are more likely to be sent to (and kept in) school than girls, the extra cost in terms of lost labor associated with primary schooling is higher for families that have sons. This, in turn, encourages parents who already have boys to reduce their fertility.

Most of the evidence of the existence of preferences for sons comes from Asian countries; relatively few inquiries have been made into such preferences in sub-Saharan Africa, which was assumed to be free or nearly free of such gender preferences. This is surprising since many of the cultural and economic factors used to explain male preference in Asia apply equally to Africa. One study that has documented significant gender bias in Africa is Anderson and Ray (2010), which found skewed sex ratios in favor of men in the composition of households at older ages. Another study (Eguavoen, Odiagbe, and Obetoh 2007), which involved a small community in Nigeria, found that almost 90 percent of surveyed respondents reported a preference for sons. What is different from the Asian context is that the bias against females in sub-Sahara Africa is present at all ages. ${ }^{5}$ Milazzo (2014) argued that gender bias is likely not found in births in Africa because high fertility is culturally valued and costs relatively little for households that rely on support from the extended family system. The preference for sons in Uganda

5 The significant biases documented in Anderson and Ray (2010) have recently been attenuated by Klasen and Vollmer (2013), which confirmed that only young adult women were missing from households. 
was extensively documented in Beyeza-Kashesya et al. (2010), albeit only qualitatively. The only quantitative assessment in Uganda to date is Bongaarts (2013), which included Uganda in a study comparing 61 countries. That study found no evidence of a preference for sons, but it used information from a household survey on the desired number of boys and girls to calculate sex ratios, which could differ markedly from actual fertility behavior.

\section{Data}

We used data from the Uganda National Household Survey (UNHS) 2005-2006 obtained directly from UBOS. Although the survey was somewhat dated, we chose it because it provided much more information about agriculture than more-recent UNHS surveys (2009-2012 and 2012-2013). The 2005-2006 survey was structured with the Living Standards Measurement StudyIntegrated Surveys on Agriculture (LSMS-ISA) ${ }^{6}$ in mind and collected detailed information on a sample of almost 43,000 people in 7,500 households in Uganda.

The ideal data set would have been a sample of households in which parents planned to have no more children. The fact that we used a cross-section of households in which women were at various stages in their reproductive lives created some problems. Parents who have been together only a short time will have a smaller-than-average household size, and a household in which only one child has been born will tell little about any male/female preferences the family may have. The fact that we were working with a cross-section of households was also reflected in the average number of children overall of 3.13. In Uganda, women typically bear about seven children during their entire reproductive periods.

To address this problem, we used the difference between the maximum reproductive capacities of women in a set of age cohorts and the number of children they reported having. ${ }^{7}$ We refer to this measure as the fertility gap. To obtain values for maximum reproductive capacity, we would have had to estimate the average age at menarche for the population and then divide that age by the periods required for pregnancy and post-pregnancy lactation infecundity. In addition, we would have had to incorporate the maternal mortality ratio as "censoring" women who, by virtue of multiple pregnancies, had a higher rate of mortality and exited from the sample. Instead, we chose to use the 95th percentile of the total fertility rate per age from the

\footnotetext{
6 LSMS-ISA is a World Bank household survey project involving eight countries in sub-Saharan Africa that aims to gather statistical panel data about households specifically related to links between agriculture and poverty reduction (http://econ.worldbank.org/WBSITE/EXTERNAL/ EXTDEC/EXTRESEARCH/EXTLSMS/0,,contentMDK:23512006 pagePK:64168445 piPK:641683 09 theSitePK:3358997,00.html).

7 Alternatively, one could use the number of children in the household and control for the age of the mother. We ran the analysis using that strategy and found that the results were nearly identical.
} 
Demographic and Health Survey of Uganda done in 2011 (UBOS 2012), which provides a good approximation of the upper bound of age of fertility in the population.

We selected households in which the head of household indicated having at least one son or daughter living with them. The UNHS data did not report children who did not live with their parents, such as adult children living on their own. Thus, when the heads of households were around 30 years of age, the gap between the reported number of their children and their theoretical fertility began to increase rapidly. Furthermore, the first-born children were most likely to have left their parents and started households of their own so the oldest child in a household was not necessarily the first-born child. To overcome these problems, we restricted our sample to households in which the mother was 16 to 32 years of age. We chose 32 as the cut-off age because at this age, the mother's first-born would turn 16, which is our entry age into the sample of mothers. This restriction offered a second advantage. For some of our indirect outcome variables such as productivity, the gender of the first-born child could have a direct effect as well, threatening the validity of our identification strategy. ${ }^{8}$ Young mothers meant that the children were relatively young also and thus were less likely to affect outcomes such as productivity directly.

One could argue that the sex of the first-born child is not particularly relevant when women bear an average of almost seven children in a lifetime. Indeed, given the high rate of fertility in Uganda, most households would have had a second child regardless of the sex of the first. This assumption is supported by Jayachandran and Kuziemko (2011), who found that differences in the duration of breastfeeding between boys and girls were largest around the family size that the household viewed as optimal, which was also the point at which a child's gender was most predictive of subsequent fertility. Therefore, we analyzed the effect of fertility using the sex of the first-born child, the sexes of the first two children, and the share of the household's children who were girls.

\section{Descriptive Statistics}

In Table 1, we report the results of the statistical analysis for the gender of the first few children born and for the share of a woman's children by gender on the number of children a woman had and fertility, which is represented by the probability that a household would have at least one more child $($ Prob +1$)$ and calculated by determining the percentage of households that had more than one or two children. We find that the gender of the first one and two children and the share of female children affect fertility. In the

8 For example, boys' effect on productivity may differ from girls' due to physical differences. 
Table 1. Gender and Fertility

\begin{tabular}{lccc}
\hline & $\begin{array}{c}\text { Probability of Having } \\
\text { Another Child }\end{array}$ & $\begin{array}{c}\text { Average } \\
\text { Fertility }\end{array}$ & $\begin{array}{c}\text { Gap in } \\
\text { Fertility }\end{array}$ \\
\hline $1 \mathrm{st}=$ boy & 0.375 & - & 2.46 \\
$1 \mathrm{st}=$ girl & 0.393 & - & 2.26 \\
$1 \mathrm{st}=$ boy, 2nd = boy & 0.132 & - & 2.46 \\
$1 \mathrm{st}=$ girl, 2nd = boy & 0.134 & - & 2.38 \\
$1 \mathrm{st}=$ girl, 2nd = girl & 0.139 & 2.78 & 2.06 \\
Percent daughters less than 0.5 & - & 2.88 & 2.41 \\
Percent daughters equal to or & - & & 2.32 \\
greater than 0.5 & & & \\
\hline
\end{tabular}

Source: Author's calculations based on UNHS 2005-2006 data.

sub-sample in which the first child was a boy, about 37 percent of households likely would have had at least one more child. When the first child was a girl, the probability of the household having another child was almost 40 percent.

We also analyzed the effect of the first-born's gender on the gap between actual and theoretical fertility and found that households in which the first child was a boy had an average fertility gap of about 2.46 children. The gap was smaller, 2.26 children, when the first-born was a girl. This significant difference $(p=0.003)$ is consistent with the proposition that households in which the first-born child is a girl are more likely to have a relatively large number of children (conditional on the mother's age).

We next analyzed the effect of the gender of the first two children born using three cases: a boy followed by a boy, a girl followed by a boy, and a girl followed by a girl. We expected that the probability of having another child would be lowest when the first two children born were boys and highest when the first two children born were girls. The results support this hypothesis, generating probabilities of 13.2 percent when the first two children were boys, 13.4 percent when the first was a girl and the second was a boy, and 13.9 percent when the first two children were girls. The gap between actual and potential household size is also largest when the first two children are boys and smallest when the first two children are girls. Finally, we proposed the share of female children in the household as a potential continuous variable to be used in the regression analysis. At this point, we simply divided the sample into households in which half or more of the children were female and households in which less than half were female. We find that the average number of children is smaller (2.78 children) when less than half of the children are girls than when half or more are girls (2.88) and that there is a significant difference in the fertility gap (p-value 0.021). The number of children in households in which girls were the majority is closest to the theoretical maximum household size. 
In this study, an important outcome variable is labor supply in agriculture, one of the prime pathways through which fertility is likely to affect productivity and well-being. The 2005-2006 UNHS records days worked on various plots reported separately for adult male and female household members. Most of Uganda has two cropping seasons-January through June and July through December-and households were interviewed twice over the course of a year-at the beginning of 2005 regarding July through December 2004 and at the end of 2005 regarding January through June 2005-to capture both. We consider only the 2004 July to December cropping season because data on labor allocations in agriculture were not available for the 2005 season.

Figure 1 shows reported time in fields for women, men, and children devoted to land preparation, input applications, weeding, and harvesting for the five crops most widely grown in Uganda. According to the data, women spent

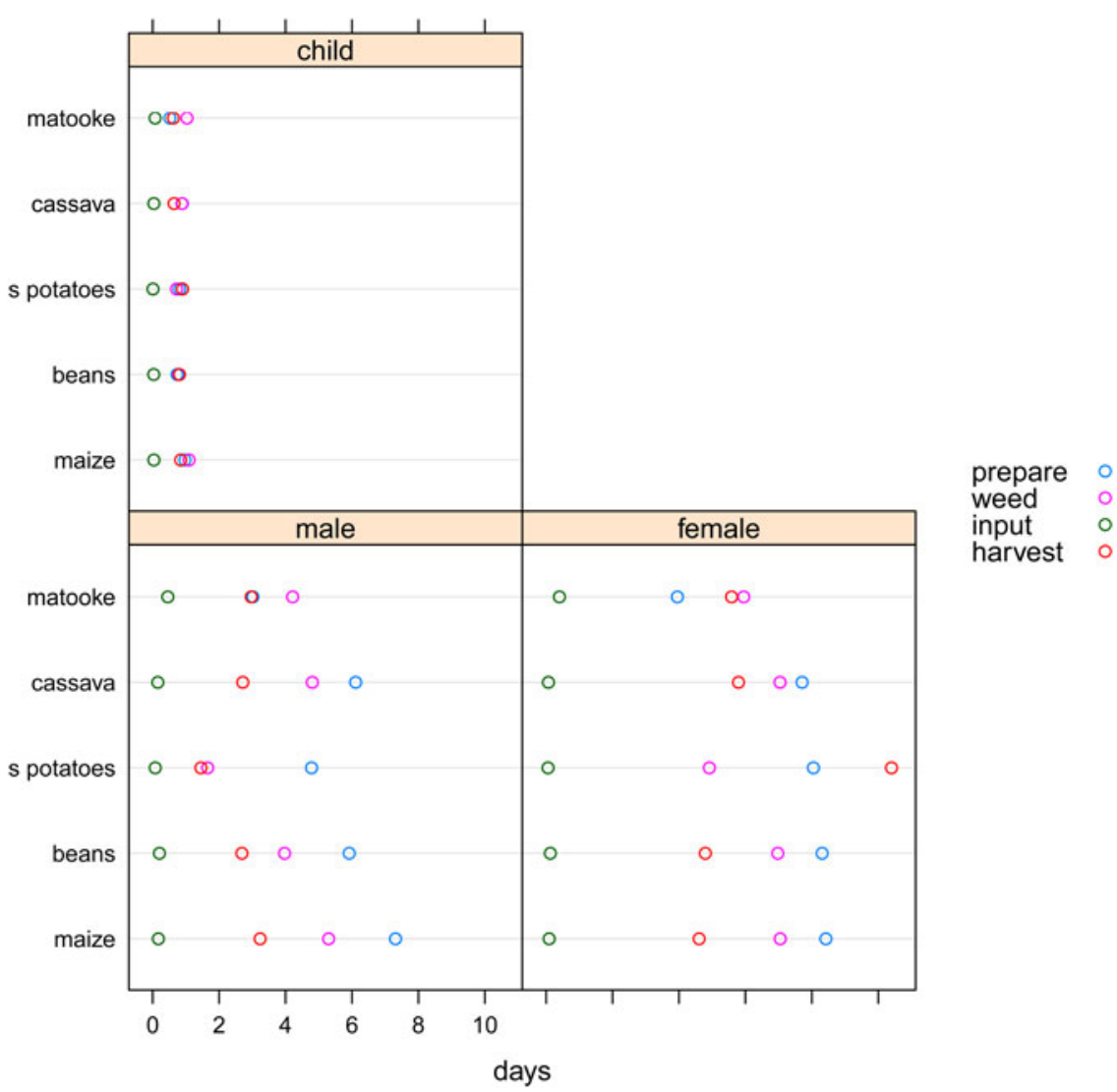

Figure 1. Average Number of Days Worked 
more time than men, a result mirrored by many studies of gender-differentiated time use in agriculture (e.g., Blackden and Wodon 2006). Evers and Walters (2001), for example, found that women in Uganda supplied 80 percent of household labor time for food production, 60 percent for production of cash crops, and most labor for care of the household. The amount of child labor reported was negligible, ${ }^{9}$ which again points to a loss of agricultural labor in the trade-off between time lost by the mother rearing children and time gained by extra hands. The short amount of time spent applying inputs is typical for Ugandan farmers, who use very limited amounts of fertilizer and other inputs. There is also some heterogeneity in the time men and women spend on different crops. For instance, women spend much more of their time cultivating sweet potatoes and somewhat more time cultivating beans than men do, suggesting some gender patterns of cropping in Uganda (Doss 2002).

We also investigate how fertility affects production of the five most commonly cultivated crops. Descriptive statistics on production are reported in Table 2. More than 50 percent of the households reported growing maize, beans, and cassavas. On average, households allocated about half an acre to maize and reserved the least space for sweet potatoes. In terms of area cultivated as a share of total area under cultivation, an average of about 17 percent was allocated to maize while only 8 percent was allocated to sweet potatoes. The average production of each crop in kilograms at the household level, which ranged from 128.5 for beans to 2,067.3 for matooke, is relatively low because the averages include households that did not produce the crop. We also divided by household size to calculate production per capita. Finally, we report yields per acre for the five main crops.

To analyze the effect of fertility on overall agricultural production, we aggregated the values of the five main crops using the average price for each crop obtained from FoodNet ${ }^{10}$ for Kampala's Nakawa market for July through December 2004. We found that the average total value derived from the crops was about 98,500 in Ugandan shillings (UGX), which translates to about 45,000 shillings per capita. ${ }^{11}$ About 40 percent of the households in which the adults were of reproductive age did not cultivate any of the crops. On average, farmers in Uganda allocated about 0.69 acres to the five main crops and produced an average value of 220,220 shillings per crop season.

\footnotetext{
9 While the relationship between fertility and child labor is an important research question, we do not consider it in the present study, in part because the data suggest that child labor occurs infrequently in Uganda. More importantly, the instruments we use (gender of first-born child and children and sex composition of children in the household) are likely to influence the number of days children work in agriculture directly rather than only through fertility, raising a risk of violation of the exclusion restriction.

10 See www.foodnet.cgiar.org.

11 At the time of the survey, one U.S. dollar was equivalent to 1,780 Ugandan shillings (abbreviated UGX).
} 
Table 2. Descriptive Statistics for Crop Production

\begin{tabular}{|c|c|c|c|c|c|}
\hline & Maize & Beans & $\begin{array}{c}\text { Sweet } \\
\text { Potatoes }\end{array}$ & Cassavas & Matooke \\
\hline $\begin{array}{l}\text { Percent of households } \\
\text { growing the crop }\end{array}$ & 59.1 & 52.6 & 38.8 & 51.8 & 43.1 \\
\hline Crop area in acres & 0.473 & 0.263 & 0.165 & 0.301 & 0.264 \\
\hline $\begin{array}{l}\text { Crop area as percent of total } \\
\text { area }\end{array}$ & 17.1 & 12.6 & 8.2 & 12.0 & 10.2 \\
\hline Production in kilograms & 38.7 & 12.8 & 85.1 & 83.2 & 348.9 \\
\hline $\begin{array}{l}\text { Production per capita in } \\
\text { kilograms }\end{array}$ & 18.1 & 6.4 & 38.7 & 38.4 & 168.6 \\
\hline Yield in kilograms per acre & 358.2 & 128.5 & $1,096.3$ & $1,030.8$ & $2,067.3$ \\
\hline
\end{tabular}

Source: Author's calculations based on UNHS 2005-2006 data.

\section{Results}

We estimate the causal impact of fertility on various agricultural outcomes using instrumental variables in a two-stage least-squares specification. The first stage regresses our proposed instruments on the fertility gap-the difference between the maximum number of children a household could have given their age and the actual number of children born. The second stage addresses the effects of fertility on agricultural labor supply, area planted, production, and productivity.

\section{The First-Stage Regressions}

Table 3 reports the results for the first-stage regressions, which link the sex of the first child/children to fertility. As previously mentioned, the dependent variable is the gap between the maximum number of children for a typical woman of a particular age and the actual number of children the women of that age bore, ${ }^{12}$ which we refer to as the fertility gap (fgap). We further include a series of control variables that are clearly exogenous to fertility. The first, femhead, is an indicator variable that takes a value of 1 when the household head is female and 0 otherwise. The second, urban, is an indicator variable that takes a value of 1 when the household resides in an urban area and 0 otherwise. ${ }^{13}$ Three dummy variables account for the mother's

\footnotetext{
12 The maximum number of children per household was estimated from data provided by the Demographic and Health Survey of Uganda (UBOS 2012) and is the 95th percentile.

13 In some of the specifications in which regional variation in the outcome variable was likely to be important, such as production and yields for some crops, we also ran a version of the model that included dummy variables for the four regions in the first-stage and second-stage equations. This addition did not significantly change the other estimated parameters in the first stage.
} 
Table 3. First Stage Regression: Ordinary Least Square Estimation of the Fertility Gap

\begin{tabular}{|c|c|c|c|c|}
\hline Variable & Model 3-1 & Model 3-2 & Model 3-3 & Model 3-4 \\
\hline \multirow[t]{2}{*}{ oldestgirl } & $-0.203^{* *}$ & - & - & - \\
\hline & $(0.067)$ & - & & - \\
\hline \multirow[t]{2}{*}{ 2oldestgirls } & - & $-0.190 *$ & & - \\
\hline & - & $(0.082)$ & & - \\
\hline \multirow[t]{2}{*}{ 3oldestgirls } & - & - & -0.147 & - \\
\hline & - & - & $(0.117)$ & - \\
\hline \multirow[t]{2}{*}{ percentfmales } & - & - & - & $-0.278^{* *}$ \\
\hline & - & - & - & $(0.094)$ \\
\hline \multirow[t]{2}{*}{ femhead } & $1.186^{* *}$ & $1.168^{* *}$ & $1.201^{* *}$ & $1.186^{* *}$ \\
\hline & $(0.098)$ & $(0.105)$ & $(0.118)$ & $(0.098)$ \\
\hline \multirow[t]{2}{*}{ urban } & $0.322^{* *}$ & $0.273^{* *}$ & 0.077 & $0.325^{* *}$ \\
\hline & $(0.083)$ & $(0.097)$ & $(0.115)$ & $(0.083)$ \\
\hline \multirow[t]{2}{*}{ mprim } & $-0.155^{*}$ & -0.025 & -0.009 & $-0.159 *$ \\
\hline & $(0.075)$ & $(0.082)$ & $(0.094)$ & $(0.075)$ \\
\hline \multirow[t]{2}{*}{ msec } & $0.259 *$ & $0.220+$ & 0.193 & $0.257^{*}$ \\
\hline & $(0.101)$ & $(0.121)$ & $(0.150)$ & $(0.101)$ \\
\hline \multirow[t]{2}{*}{ mthird } & $1.058^{* *}$ & $0.914^{* *}$ & $0.755+$ & $1.060^{* *}$ \\
\hline & $(0.192)$ & $(0.250)$ & $(0.403)$ & $(0.192)$ \\
\hline \multirow[t]{2}{*}{ health } & 0.095 & 0.107 & 0.151 & 0.090 \\
\hline & $(0.124)$ & $(0.146)$ & $(0.171)$ & $(0.124)$ \\
\hline \multirow[t]{2}{*}{ school } & 0.040 & -0.005 & -0.118 & 0.043 \\
\hline & $(0.070)$ & $(0.078)$ & $(0.090)$ & $(0.070)$ \\
\hline \multirow[t]{2}{*}{ cdied } & $0.284^{* *}$ & $0.204+$ & 0.117 & $0.285^{* *}$ \\
\hline & $(0.100)$ & $(0.108)$ & $(0.127)$ & $(0.100)$ \\
\hline \multirow[t]{2}{*}{ Constant } & $2.172^{* *}$ & $1.946^{* *}$ & $1.782^{* *}$ & $2.209^{* *}$ \\
\hline & $(0.074)$ & $(0.075)$ & $(0.079)$ & $(0.081)$ \\
\hline R-squared & 0.091 & 0.075 & 0.065 & 0.091 \\
\hline$N$ & 2,656 & 2,036 & 1,391 & 2,656 \\
\hline
\end{tabular}

Note: Huber-White standard errors are shown in parentheses, and,$+{ }^{*}$, and ${ }^{* *}$ denote significance at the 10 percent, 5 percent, and 1 percent level respectively.

education level: mprim takes a value of 1 if the mother completed her primary education, msec represents the additional effect of the mother having completed secondary education, and mthird represents the additional effect of the mother having completed tertiary education. The comparison category, therefore, is 
households in which the mother did not complete primary education. We include two community variables that are likely to influence household size: school, which is a dummy variable that takes a value of 1 when there was a school in the village, and health, another dummy variable that takes a value of 1 when there was a public health center or clinic in the community. Finally, we use an indicator, cdied, that takes a value of 1 if a son or daughter of the mother had died in the past.

We conducted the first-stage regressions for four alternative instruments and report the results in Table 3. In model 3-1, the excluded instrument (oldestgirl) takes a value of 1 when the first-born in the household was a girl. The estimated coefficient, -0.203 , is significant at the 1 percent level and has the expected signwhen the first-born child is a girl, the fertility gap is reduced by about 0.2 children. In other words, households in which the first-born was a girl had more children on average than families in which the first-born was a boy. We also found that households headed by women had a significantly larger fertility gap of about 1.0 children. Urban households also seemed to have significantly fewer children. In terms of education, the fertility gap was slightly smaller (compared to women with no education) for women with only an elementary education and somewhat larger for women who had obtained higher levels of education. The health and school community variables did not affect fertility. Finally, the death of a child in the family led to a relatively small but significant additional fertility gap (0.284) compared to households that had not lost a child. The small magnitude of the additional gap suggests a substantial replacement effect: households that lost a child are likely to try again.

In model 3-2, the excluded instrument is an indicator variable that equals 1 when the first two children born to the mother in the household were both girls (2oldestgirls). Thus, we confine this regression to households that had at least two children, resulting in a smaller sample size. The coefficient on the excluded instrument is significantly negative, which is in line with our hypothesis, and the coefficients on the control variables are nearly identical to the estimates from model 3-1.

The regression in model 3-3 goes one step further and considers the first three children born to the mother: the excluded instrument is an indicator of households in which the first three children born were all girls (3oldestgirls). This naturally limited the size of the sample even further $(N=1,391)$. In this case, the coefficient is negative but is no longer significant, and we suspect that the small sample size excessively reduced the power of the t-test.

Finally, model 3-4 uses a continuous variable, the share of a household's children who are girls, as the excluded instrument (percentfemales). The coefficient on this instrument also has the expected sign: a larger share of female children in households is associated with a smaller fertility gap. This is consistent with the results of a study by Jayachandran and Kuziemko (2011), who observed that the "try until you have a boy" fertility rule led to larger households having more girls on average than smaller households. The results for the other variables are similar to the results reported in the other three models. 
Overall, the results of these regressions suggest that a daughters-only household (percentfemales $=1$ ) is, on average, 0.28 children larger than a sons-only household (percentfemales $=0$ ).

While most of our instrumental variables are statistically significant and have expected signs, they explain only a small part of observed variances in the fertility gap. When we regressed the excluded instruments one by one on the dependent variable, the R-squares dropped below 1 percent. The F-value of a regression using only the excluded instruments, which is an important indicator of the strength of the instruments according to Bound, Jaeger, and Baker (1995), also dropped, to $9.46 .{ }^{14}$ Thus, there was reason to believe that the instruments used in the first-stage regressions were weak and thus to use inference methods that were robust to weak instruments. In particular, we relied on the Anderson-Rubin test statistic to gauge the significance of the endogenous variable in all subsequent regressions, as suggested in Staiger and Stock (1997).

\section{Effect of Fertility on Household Labor Allocation}

Table 4 shows regressions estimating the effect of fertility (measured by the fertility gap) on total time (number of days) worked in household agriculture in a year. ${ }^{15}$ Model 4-1 reports the results of an ordinary least squares (OLS) regression that does not take endogeneity of the fertility gap into account. We find no significant correlation between the number of days worked and fertility based on the estimated fertility gap. There is a significant negative effect of women as heads of households (femhead) and households located in urban areas (urban). Primary and secondary education of mothers (mprim and msec) shows no systematic relationship to number of days worked in agriculture, but mothers who had advanced education (mthird) spent less time on agricultural work. The OLS estimates for a community school and the death of a child in the household are positively correlated with days worked by the parents. Finally, we find some evidence of a negative effect of health centers on hours worked.

Models 4-2, 4-3, and 4-4 use the same general specification as 4-1 but take the endogeneity of the fertility gap into account using a single excluded instrument in two-stage least squares regressions (2SLS). In model 4-2, the instrument is an indicator that takes a value of 1 when the first-born was a girl (corresponding to first-stage model 3-1). In this case, the coefficient on the fertility gap is positive and significant at a 10 percent level, implying that greater fertility (a smaller gap) reduces the number of days parents worked on family fields. Model 4-3 uses the sex of the first-born and second-born as instruments for the fertility gap (corresponding to model 3-2) while model 4-4 uses the share of a

\footnotetext{
14 Instruments with an F-statistic smaller than 10.0 are generally considered weak.

15 We ran the same models using days worked per acre of land held by the household. However, the average household works only about 1.1 acres and there seems to be no systematic relationship between farm size and labor supply so the results were nearly identical.
} 
Table 4. Effect of Fertility on Total Time Worked in Agriculture

\begin{tabular}{|c|c|c|c|c|c|}
\hline Variable & $\begin{array}{l}\text { Model 4-1 } \\
\text { OLS }\end{array}$ & $\begin{array}{l}\text { Model 4-2 } \\
\text { 2SLS }\end{array}$ & $\begin{array}{l}\text { Model 4-3 } \\
\text { 2SLS }\end{array}$ & $\begin{array}{l}\text { Model 4-4 } \\
\quad \text { 2SLS }\end{array}$ & $\begin{array}{l}\text { Model 4-5 } \\
\text { LIML }\end{array}$ \\
\hline fgap & $\begin{array}{c}-0.122 \\
(1.245)\end{array}$ & $\begin{array}{c}46.799+ \\
(32.112)\end{array}$ & $\begin{array}{c}64.297+ \\
(48.865)\end{array}$ & $\begin{array}{l}69.227^{* *} \\
(35.208)\end{array}$ & $\begin{array}{l}66.349 * * \\
(36.319)\end{array}$ \\
\hline femhead & $\begin{array}{c}-38.213^{* *} \\
(4.793)\end{array}$ & $\begin{array}{r}-95.268^{*} \\
(39.623)\end{array}$ & $\begin{array}{c}-116.211+ \\
(59.496)\end{array}$ & $\begin{array}{c}-122.540^{* *} \\
(44.167)\end{array}$ & $\begin{array}{c}-119.040^{* *} \\
(45.268)\end{array}$ \\
\hline urban & $\begin{array}{c}-23.411^{* *} \\
(5.780)\end{array}$ & $\begin{array}{c}-35.338^{* *} \\
(11.352)\end{array}$ & $\begin{array}{c}-40.541^{* *} \\
(13.796)\end{array}$ & $\begin{array}{c}-41.038^{* *} \\
(13.622)\end{array}$ & $\begin{array}{c}-40.307^{* *} \\
(13.516)\end{array}$ \\
\hline mprim & $\begin{array}{c}1.392 \\
(4.897)\end{array}$ & $\begin{array}{c}8.132 \\
(7.802)\end{array}$ & $\begin{array}{c}6.058 \\
(8.092)\end{array}$ & $\begin{array}{l}11.354 \\
(9.128)\end{array}$ & $\begin{array}{l}10.940 \\
(9.065)\end{array}$ \\
\hline msec & $\begin{array}{c}-6.121 \\
(6.516)\end{array}$ & $\begin{array}{r}-10.595 \\
(8.899)\end{array}$ & $\begin{array}{c}-7.207 \\
(11.617)\end{array}$ & $\begin{array}{r}-12.734 \\
(11.167)\end{array}$ & $\begin{array}{l}-12.459 \\
(10.850)\end{array}$ \\
\hline mthird & $\begin{array}{r}-20.792^{*} \\
(9.946)\end{array}$ & $\begin{array}{c}-70.642+ \\
(39.814)\end{array}$ & $\begin{array}{l}-83.864 \\
(54.795)\end{array}$ & $\begin{array}{r}-94.470^{*} \\
(45.224)\end{array}$ & $\begin{array}{r}-91.412^{*} \\
(46.122)\end{array}$ \\
\hline health & $\begin{array}{r}-15.118^{*} \\
(7.694)\end{array}$ & $\begin{array}{c}-21.809^{*} \\
(11.099)\end{array}$ & $\begin{array}{r}-18.573 \\
(14.923)\end{array}$ & $\begin{array}{c}-25.008+ \\
(13.928)\end{array}$ & $\begin{array}{c}-24.597+ \\
(13.544)\end{array}$ \\
\hline school & $\begin{array}{l}12.570^{* *} \\
(4.793)\end{array}$ & $\begin{array}{c}7.633 \\
(6.914)\end{array}$ & $\begin{array}{c}9.887 \\
(9.145)\end{array}$ & $\begin{array}{c}5.274 \\
(7.881)\end{array}$ & $\begin{array}{c}5.576 \\
(7.879)\end{array}$ \\
\hline cdied & $\begin{array}{l}13.573^{*} \\
(6.273)\end{array}$ & $\begin{array}{c}3.161 \\
(10.788)\end{array}$ & $\begin{array}{r}1.904 \\
(12.672)\end{array}$ & $\begin{array}{r}-1.816 \\
(12.954)\end{array}$ & $\begin{array}{c}-1.177 \\
(12.801)\end{array}$ \\
\hline Constant & $\begin{array}{c}87.193^{* *} \\
(4.718)\end{array}$ & $\begin{array}{c}-7.527 \\
(64.960)\end{array}$ & $\begin{array}{l}-29.950 \\
(90.557)\end{array}$ & $\begin{array}{l}-52.803 \\
(70.927)\end{array}$ & $\begin{array}{l}-46.992 \\
(73.206)\end{array}$ \\
\hline$N$ & 2,016 & 2,016 & 1,620 & 2,016 & 2,016 \\
\hline Instrument & - & $1 \mathrm{st}=$ girl & $\begin{array}{c}\text { 1st and } \\
2 \text { nd }=\text { girl }\end{array}$ & Percent girl & $\begin{array}{c}1 \mathrm{st}=\text { girl and } \\
\text { percent girl }\end{array}$ \\
\hline
\end{tabular}

Note: Huber-White standard errors are shown in parentheses, and,$+{ }^{*}$, and ${ }^{* *}$ denote significance at the 10 percent, 5 percent, and 1 percent level respectively.

household's children who were daughters (corresponding to model 3-4). Relative to the OLS regressions, these estimates of the effect on fertility in two-stage regressions are larger and are significant at a 1 percent level.

Model 4-5 uses both the gender of the first-born and the share of children who are daughters as excluded instruments and is estimated using limitedinformation maximum likelihood (LIML). ${ }^{16}$ Based on the Hansen J-statistic,

\footnotetext{
16 An LIML regression provides better small-sample properties than a 2SLS regression in an over-identified model with weak instruments (Angrist and Krueger 2001).
} 
we could not reject the null hypothesis that our instruments were valid (Hansen $\mathrm{J}=0.849, \mathrm{p}=0.357$ ). In this specification, an increase in the fertility gap of one child is associated with an additional 66 days of agricultural labor by the parents. Regarding the other variables in the regression, the only significant result is a reduction in agricultural labor associated with women who have obtained an advanced education.

These results point to a substantial effect of fertility on labor time, and in an environment such as Uganda that is characterized by semi-subsistence agriculture, such a dramatic drop in time allocated to agricultural activities at the household level in response to additional children is bound to affect the household's well-being and food security. But looking only at fertility's effect on the aggregate labor supply provides limited insight into how well-being and food security are affected. We therefore conducted separate 2SLS regressions of the supply of household labor provided by adult men and by adult women in the households and report the coefficients on the fertility gap in Table 5. The regressions included the same exogenous control variables as the OLS regression.

In model 5-1 (the OLS regression), the estimate of the effect of fertility on women's labor is not significant. When we account in model 5-2 for the endogeneity of fertility using exogenous variation caused by the sex of the first-born, the effect of the fertility gap is significant at a 5 percent level; an increase in the fertility gap per age cohort of one child is associated with an additional 30 days of participation in agricultural labor by women in the household. The significance of the effect of fertility on women's labor in the other models $(5-3,5-4$, and 5-5) is essentially the same as in the models for agricultural labor generally. On average, an additional child is associated with a 40-day reduction in agricultural labor by women.

Table 5. Two-stage Least Square Estimates of Household Labor Supply

\begin{tabular}{|c|c|c|c|c|c|}
\hline & $\begin{array}{l}\text { Model 5-1 } \\
\text { OLS }\end{array}$ & $\begin{array}{c}\text { Model 5-2 } \\
\text { 2SLS }\end{array}$ & $\begin{array}{l}\text { Model 5-3 } \\
\text { 2SLS }\end{array}$ & $\begin{array}{c}\text { Model 5-4 } \\
\text { 2SLS }\end{array}$ & $\begin{array}{l}\text { Model 5-5 } \\
\text { LIML }\end{array}$ \\
\hline \multirow{2}{*}{$\begin{array}{c}\text { Days worked } \\
\text { by mother }\end{array}$} & 0.533 & $29.890^{*}$ & $54.070^{* *}$ & $40.841^{* *}$ & $38.773^{* *}$ \\
\hline & $(0.735)$ & (17.769) & (33.364) & (19.353) & (19.085) \\
\hline \multirow{2}{*}{$\begin{array}{c}\text { Days worked } \\
\text { by father }\end{array}$} & -0.620 & 10.928 & 5.915 & $22.327^{*}$ & $20.076+$ \\
\hline & $(0.668)$ & (13.983) & (25.595) & $(13.580)$ & $(14.756)$ \\
\hline$N$ & 2,016 & 2,016 & 1,620 & 2,016 & 2,016 \\
\hline Instrument & - & $1 \mathrm{st}=\operatorname{girl}$ & $\begin{array}{c}\text { 1st and } \\
2 \text { nd = girl }\end{array}$ & $\begin{array}{l}\text { Percent } \\
\text { girl }\end{array}$ & $\begin{array}{c}1 \mathrm{st}=\text { girl and } \\
\text { percent girl }\end{array}$ \\
\hline
\end{tabular}

Note: Huber-White standard errors are shown in parentheses, and,$+{ }^{*}$, and ${ }^{* *}$ denote significance at the 10 percent, 5 percent, and 1 percent level respectively. 
We next analyzed the effect of fertility on the supply of male labor in a household. As with female labor, we found that the fertility gap was not correlated with the male labor supply when we did not account for the endogenous nature of fertility choices. In the 2SLS models that accounted for the endogeneity of fertility (5-2 through 5-5), the effect of fertility on the male labor supply was less clear-cut than the effect on the female labor supply. When we used the sex of the first-born (model 5-2) and of the first two children born (model 5-3) as instruments, the coefficients were not significantly different from zero. When we used the share of all of a household's children who were female, we found that an additional child was correlated with a reduction in the male labor supply about half the size of the reduction in the female labor supply. Model 5-5 produces estimates that are significant only at the 10 percent level.

Our estimates of the effect of fertility on household labor are generally in line with the results of studies of developed countries and are particularly consistent with the results of studies of developing agricultural countries. In a study of the U.S. labor supply's response to fertility, for instance, Angrist and Evans (1998) found that women worked less while men worked about the same amount of time as the number of children in the household increased, and Kim and Aassve (2006) found that urban and rural Indonesian women reduced their working days in response to greater fecundity. Thus, our results provide additional support for the notion that male labor and female labor in a household are not perfect substitutes, a disparity that contributes to income inequality between men and women. It may also lead to the production inefficiencies observed for plots managed by women because women cannot devote as much time to field work (Udry 1996). Our analysis clearly shows that increased fertility is associated with greater time poverty, which will have a detrimental effect on agricultural efforts and on the overall well-being of the household and will escalate with each additional child, presenting parents in general and women in particular (Bardasi and Wodon 2010) with difficult decisions. A larger family requires more childcare and more food while allocating additional labor to taking care of children potentially reduces the amount of food that can be produced. Women's time poverty also could restrict opportunities for education for them and their children (Arora 2015).

Table 6 reports the results of a 2SLS regression estimating the effects of fertility on overall household labor allocations for specific types of agricultural activities: land preparations, input applications, weeding, and harvesting. Again, the table reports the estimated coefficients for the fertility gap only, but other exogenous variables from Table 4 were included in the regression. We found no significant effect of fertility on household allocation of labor in the OLS results. We thus focus mostly on the LIML results, which we deem most credible. In terms of the individual activities, an additional child reduced the time allocated to land preparation by about 25 days. None of the coefficients for input applications were significant since Ugandan 
Table 6. Two-stage Least Square Estimates of Household Labor Allocation

\begin{tabular}{|c|c|c|c|c|c|}
\hline $\begin{array}{l}\text { Time } \\
\text { Allocated }\end{array}$ & $\begin{array}{c}\text { Model 6-1 } \\
\text { OLS }\end{array}$ & $\begin{array}{l}\text { Model 6-2 } \\
\text { 2SLS }\end{array}$ & $\begin{array}{l}\text { Model 6*3 } \\
\text { 2SLS }\end{array}$ & $\begin{array}{l}\text { Model 6-4 } \\
\text { 2SLS }\end{array}$ & $\begin{array}{l}\text { Model 6-5 } \\
\text { LIML }\end{array}$ \\
\hline \multirow{2}{*}{$\begin{array}{l}\text { Land } \\
\quad \text { preparation }\end{array}$} & -0.048 & 15.876 & $41.127^{* *}$ & $26.028^{* *}$ & $25.278^{*}$ \\
\hline & $(0.528)$ & (12.737) & $(25.884)$ & $(13.720)$ & (14.761) \\
\hline \multirow{2}{*}{$\begin{array}{l}\text { Input } \\
\text { applications }\end{array}$} & 0.051 & 1.812 & 0.849 & 2.372 & 2.224 \\
\hline & $(0.136)$ & (1.632) & $(1.686)$ & $(1.829)$ & $(1.741)$ \\
\hline \multirow[t]{2}{*}{ Weeding } & 0.026 & $17.708^{*}$ & $25.959^{*}$ & $21.385^{*}$ & $20.492^{*}$ \\
\hline & $(0.468)$ & (11.724) & $(17.541)$ & $(11.730)$ & (11.253) \\
\hline \multirow[t]{2}{*}{ Harvesting } & -0.082 & 5.315 & -3.591 & $13.852+$ & $12.485+$ \\
\hline & $(0.468)$ & (10.597) & $(20.563)$ & (8.987) & (10.379) \\
\hline$N$ & 2,015 & 2,015 & 1,619 & 2,015 & 2,015 \\
\hline Instrument & - & $1 \mathrm{st}=$ girl & $\begin{array}{l}\text { 1st and } \\
2 \mathrm{nd}=\text { girl }\end{array}$ & $\begin{array}{l}\text { Percent } \\
\text { girl }\end{array}$ & $\begin{array}{c}1 \text { st }=\text { girl and } \\
\text { percent girl }\end{array}$ \\
\hline
\end{tabular}

Note: Huber-White standard errors are shown in parentheses, and,$+{ }^{*}$, and ${ }^{* *}$ denote significance at the 10 percent, 5 percent, and 1 percent level respectively.

households rarely use inputs such as fertilizers (see Figure 1) and spend only about one day per season planting. The only significant effect in these regressions was for households in which the mother had at least a primary school education; those households allocated more time to input applications (Van Campenhout 2014).

The results for weeding were similar to those for land preparation but smaller in magnitude. Each additional child reduced time allocated to weeding by about 20 days. As shown in the full results in Van Campenhout (2014) greater fertility also had a significant negative effect on weeding in female-headed households and households in urban areas. We also found that households in communities that had a health center spent fewer days weeding.

We found no significant association between greater fertility and harvesting activities in the binary OLS regression (model 6-1). For the other regressions, the only positive effect for the fertility gap was in the model in which the exclusion instrument was the share of the household's children who were girls, and that effect was small compared to the other effects for harvesting.

These results suggest that greater fertility has a particularly negative effect on the time women allocate to land preparation and weeding (since men's allocation of time to these activities does not change significantly). Differences in time allocated to harvesting do not seem to be related to family size. Families likely must allocate most of their labor to harvesting when the crops are ripe regardless of family size. Reductions in time 
allocated to weeding and land preparation, on the other hand, are likely to affect yields since weeds compete for sunlight and nutrients and time-sensitive crops may not be grown or may be planted to fewer acres.

\section{Area Planted, Production, and Productivity}

Table 7 reports coefficients for the fertility gap from 2SLS regressions of planting, production, and yields for the five most important crops in the model in which the share of a household's children who are girls is the instrumental variable. These regressions include all of the control variables used in the previous models plus regional dummy variables since some crops are more prevalent in particular regions. When the dependent variable is binary or censored, we estimate a Tobit or probit model using the methods described in Newey (1987).

We first analyze the effect of the fertility gap on the probability that a household will grow each crop. We find that the fertility gap has no effect on cultivation of maize but is positively associated with cultivation of sweet potatoes and production of matooke. In terms of acres planted to each crop, the results show a positive association between the fertility gap and the area used to grow matooke and no association for the other crops. We considered the possibility that relatively small households that planted a large number of

\section{Table 7. Two-stage Least Square Estimates of Effect of Fertility on Crop Mix, Area, Production, and Yield}

\begin{tabular}{lccccc}
\hline & Maize & Beans & $\begin{array}{c}\text { Sweet } \\
\text { Potatoes }\end{array}$ & Cassavas & Matookes \\
\hline \multirow{2}{*}{ Growing } & 0.431 & -0.193 & $0.556+$ & -0.003 & $0.622+$ \\
& $(0.359)$ & $(0.332)$ & $(0.401)$ & $(0.302)$ & $(0.428)$ \\
Total area & 0.432 & -0.119 & 0.187 & 0.105 & $0.603+$ \\
& $(0.425)$ & $(0.199)$ & $(0.254)$ & $(0.289)$ & $(0.425)$ \\
Area share & 0.028 & -0.085 & $0.169+$ & -0.027 & 0.043 \\
& $(0.087)$ & $(0.080)$ & $(0.115)$ & $(0.081)$ & $(0.081)$ \\
Production & 56.799 & -4.677 & 182.878 & 29.714 & $1931.785+$ \\
& $(71.795)$ & $(22.600)$ & $(176.010)$ & $(189.684)$ & $(1255.565)$ \\
Production & 26.593 & -1.079 & 55.706 & -11.725 & $2026.613^{*}$ \\
per capita & & & & & $(103.129)$ \\
Yield & $(38.247)$ & $(12.727)$ & $(87.191)$ & $(135.716)$ \\
& -22.060 & 41.329 & 69.834 & -480.421 & -383.889 \\
& $(169.179)$ & $(54.371)$ & $(694.248)$ & $(728.459)$ & $(882.517)$ \\
\hline
\end{tabular}

Note: Huber-White standard errors are shown in parentheses, and,$+{ }^{*}$, and ${ }^{* *}$ denote significance at the 10 percent, 5 percent, and 1 percent level respectively. All regressions use the share of household children who are girls as the instrumental variable. 
Table 8. Two-stage Least Square Estimates of Total Production

\begin{tabular}{lccccc}
\hline & Model 8-1 & Model 8-2 & Model 8-3 & Model 8-4 & Model 8-5 \\
& OLS & 2SLS & 2SLS & 2SLS & LIML \\
\hline Production $\times$ & -3.411 & 21.056 & -20.275 & 16.988 & 19.334 \\
$\quad$ UGX1,000 & $(2.697)$ & $(46.911)$ & $(57.977)$ & $(48.493)$ & $(44.172)$ \\
Production/ & $4.133^{* *}$ & 10.501 & -9.251 & 14.518 & 12.340 \\
$\quad$ capita $\times$ UGX1,000 & $(1.527)$ & $(26.009)$ & $(24.107)$ & $(27.183)$ & $(24.605)$ \\
Area & -0.033 & 0.120 & 0.042 & 0.145 & 0.132 \\
& $(0.023)$ & $(0.343)$ & $(0.443)$ & $(0.359)$ & $(0.325)$ \\
Yield & -1.697 & 43.088 & -96.861 & 0.013 & 8.818 \\
& $(2.862)$ & $(81.451)$ & $(140.870)$ & $(61.118)$ & $(69.674)$ \\
Instrument & - & 1 st $=$ girl & 1 st and & Percent & 1st= girl and \\
& & & 2nd = girl & girl & percent girl \\
\hline
\end{tabular}

Note: Huber-White standard errors are shown in parentheses, and,$+{ }^{*}$, and ${ }^{* *}$ denote significance at the 10 percent, 5 percent, and 1 percent level respectively.

acres to matooke had relatively large land holdings so we analyzed the effect of fertility for the share of area planted to each crop as well. An additional benefit was the ability to evaluate the relative importance of each crop for the household. These results showed that larger households allocated a smaller share of land to sweet potatoes. In terms of kilograms of production, a smaller fertility gap (greater fertility) was associated with production of significantly less matooke, and that association persisted when we analyzed production per capita. We found no significant effect from fertility on the average yields of each crop.

Our results for planting, production, and productivity are consistent with results from Ali et al. (2015), which found significant differences in cropping patterns for plots managed by men versus women. Women cultivated a greater number of acres of roots, pulses, and oilseeds while men cultivated a greater number of acres of cereals, bananas, and cash crops such as coffee. In light of our results, the gender differences found by Ali et al. (2005) for bananas may be related to time constraints associated with high fertility. For roots and tubers, on the other hand, Ali et al.'s (2015) finding that female managers cultivated more of those crops should be attributed to factors other than fertility, such as, for example, preferences. Matooke is the only perennial crop in our analysis, and perennial crops require greater planning than annuals. In addition, Ugandans might tend to view sweet potatoes as a woman's crop given the concentration of female labor in planting them shown in Figure 1. These results are also consistent with our previous finding that fertility is negatively correlated with land preparation.

These results have significant consequences. Matooke grows in bunches that can be stored and is harvested throughout the year (about 18 months after 
planting). Thus, with some planning, households that cultivate matooke can have a nearly constant source of food and significant food security. Sweet potatoes are the primary source of vitamin A in Ugandan diets, and children who do not obtain enough vitamin A have a higher mortality rate because of common childhood infections such as diarrheal diseases and measles and, when the deficiency is severe, can go blind.

In a final analysis, we conducted regressions for the total productivity (yield) and value of crops produced by the household in Ugandan shillings using five models similar to the ones used in the previous analyses (Table 8). In some cases, rather than OLS, we used a probit or Tobit model that did not take heterogeneity into account (8-1) depending on the nature of the dependent variable. As before, model 8-2 used the sex of the first-born as the instrument variable, model 8-3 used the sex of the first two children born, and model 8-4 used the share of children in a household who were girls. The LIML model (8-5) used two instruments: sex of the first-born and the share of children in the household who were girls. We found no association between fertility and the total value of production for the household of the five crops. The results from the first-stage model (8-1) point to a positive association between fertility and production per capita. However, when we confined ourselves to the exogenous effect of fertility in the regressions using instrumental variables, the effect disappeared. We further found no significant associations between fertility and total crop area or productivity, which was defined as the total value of the crops divided by the total area allocated to them, and no causal impact from family size.

\section{Discussion and Conclusions}

This study examines the effect of the fertility of households in Uganda on time spent working in agriculture, planting, production, and productivity by these primarily subsistence farmers. Fertility is defined as the number of biological children born to a mother. We use an identification strategy that relies on the premise that patrilineal societies such as Uganda's tend to prefer boys to girls. Thus, a household in which the first-born child is a girl is relatively more likely than a household in which the first child is a boy to have additional children (hoping to have boys). The fact that the sex of the first child born is exogenous is used to identify the causal impacts of additional children on labor supply and productivity variables. Similarly, the widely documented fertility rule in which families in patrilineal societies tend to stop having children once they have at least one boy means that households with a relatively large number of children typically have more girls than boys. Therefore, the share of children in the family who are girls can also be used as an instrumental variable. Our measure of fertility is the difference between the maximum number of children a woman in the household could bear given her age and the number of children born to the household-the "gap" in fertility; the larger the gap, the less fertile the household. We conducted a 
series of first-stage OLS regressions that did not take the endogeneity of fertility into account and then delved further into the effects of fertility using 2SLS regressions.

The results of our first-stage regressions point to significant negative effects on fertility when the first-born child is a girl and when the first two children born are girls. In addition, a large proportion of children in a household being girls is positively related to fertility (negatively related to the fertility gap). The coefficients from these first-stage regressions are significant and have the correct signs, but their explanatory power as measured by the partial R-square is low. We therefore use inference methods in the secondstage regressions that are robust to weak instruments.

In terms of household labor allocations and crop production, the results of our second-stage regressions suggest that fertility affected the amount of time both women and men allocated to agricultural production in general, and land preparation and weeding activities in particular suffered as the number of children in a household increased. Most of the labor time lost from an exogenous increase in children was borne by women. Of the five main crops grown in Uganda (maize, beans, sweet potatoes, cassavas, and matookes), only matooke and sweet potatoes were significantly affected by increases in fertility. Matooke is the most important staple crop in Uganda, providing 18 percent of caloric intake (Haggblade and Dewina 2010), so a reduction in matooke could have significant negative consequences for a family's food security and nutrition. Sweet potatoes provide small returns to the amount of labor required but are also a relatively resilient crop (Dercon 1996) and primary dietary source of vitamin A. Their production is mostly under the control of women, who do much of the work in the fields. We do not find significant effects on yields or on overall production.

Our reliance on a cross-section of households and restriction of the sample to relatively young women 16 to 32 years of age limit the extent to which our conclusions can be generalized. Couples who have a relatively large number of children might profit much more from larger households at a later stage in life. For instance, a small number of children could give a mother more time to work in agricultural activities, and children could provide inexpensive, flexible labor as they get older.

Significant policy issues are associated with fertility and its effect on households' agricultural labor and production in economies such as Uganda's. First, our analysis confirms the need for fertility-reduction policies. In addition to policies that have already shown to reduce fertility, such as education and improved health care for women, programs should identify and address the root causes of high rates of fertility. Our results show that the tendency to prefer boys to girls is one underlying cause, and there are numerous ways to change such cultural views. For example, Uganda could consider changing its laws as Kenya recently did to give equal inheritance rights to men and women. Policies should also address cultural issues related to gender roles and fertility. Some of these kinds of changes are likely to meet considerable resistance and 
any effort to change cultural values tends to be a very slow process. While fertility-reducing policies are being developed and implemented, the Ugandan government could provide nutritional support to young families and should consider introducing labor-saving agricultural technologies targeted to women.

Efforts to reduce fertility, including education, basic health care, and family planning, are likely to reduce time pressure for women and increase allocation of their labor to agricultural activities. Other policies could reduce the time burden associated with reproduction. For example, Uganda could established an organized system of childcare that would take advantage of economies of scale by bringing groups of children together to be cared for by one person. Technical agricultural and household innovations could focus on processes that are particularly time consuming for women, further freeing them to contribute their labor to production of food. Women are also likely to benefit from basic infrastructure improvements such as readily available clean water and local medical clinics.

It is important for any future policies and agricultural technologies to carefully consider whether the consequences of such developments affect men and women differently. For example, promoting use of oxen for preparing land for planting is likely to further increase women's time pressure, as the burden of weeding and especially harvesting falls disproportionately on women. Women must be able to use tools and technologies meant to make land preparation and weeding more efficient or effective. Equally important is providing extension and training for new technologies with women in mind. Norms and customs play significant roles in the agricultural activities performed by men and women and the norms can be highly context-specific (Deere 1982). Efforts to change those norms and customs could affect how time is allocated to various agricultural activities by households.

The effects of fertility on production of various crops in Uganda point to specific needs by large families for greater production of crops such as matooke, which can be produced year round and withstand storage, thus potentially providing a reliable source of food. Sweet potatoes, on the other hand, provided a limited supply of food. Policies can support cultivation of matooke as well as promote smaller families.

\section{References}

Agarwal, B. 1994. A Field of One's Own: Gender and Land Rights in South Asia. New York, NY: Cambridge University Press.

Alderman, H., and E.M. King. 1998. "Gender Differences in Parental Investment in Education." Structural Change and Economic Dynamics 9(4): 453-468.

Ali, D.A., D. Bowen, K. Deininger, and M.F. Duponchel. 2015. "Investigating the Gender Gap in Agricultural Productivity: Evidence from Uganda." Policy Research Working Paper 7262, World Bank, Washington, DC.

Anderson, S., and D. Ray. 2010. "Missing Women: Age and Disease." Review of Economic Studies 77(4): 1262-1300. 
Angrist, J.D., and W.N. Evans. 1998. “Children and Their Parents' Labor Supply: Evidence from Exogenous Variation in Family Size." American Economic Review 88(3): 450-477.

Angrist, J.D., and A.B. Krueger. 2001. "Instrumental Variables and the Search for Identification: From Supply and Demand to Natural Experiments." Journal of Economic Perspectives 15(4): 69-85.

Angrist, J., V. Lavy, and A. Schlosser. 2010. "Multiple Experiments for the Causal Link between the Quantity and Quality of Children." Journal of Labor Economics 28(4): 773-824.

Arnold, F., M. Choe, and T. Roy. 1998. "Son Preference, the Family-building Process, and Child Mortality in India." Population Studies 52(3): 301-315.

Arora, D. 2015. “Gender Differences in Time-poverty in Rural Mozambique." Review of Social Economy 73(2): 196-221.

Bardasi, E., and Q. Wodon. 2010. "Working Long Hours and Having No Choice: Time Poverty in Guinea." Feminist Economics 16(3): 45-78.

Becker, G.S. 1960. "An Economic Analysis of Fertility." In Demographic and Economic Change in Developed Countries, NBER Chapters, 209-240. National Bureau of Economic Research, Cambridge, MA.

Becker, G.S., and H.G. Lewis. 1973. "On the Interaction between the Quantity and Quality of Children." Journal of Political Economy 81(2): S279-S288.

Behrman, J.R. 1988. "Intrahousehold Allocation of Nutrients in Rural India: Are Boys Favored? Do Parents Exhibit Inequality Aversion?" Oxford Economic Papers 40(1): 32-54.

Behrman, J.R., R.A. Pollak, and P. Taubman. 1982. "Parental Preferences and Provision for Progeny." Journal of Political Economy 90(1): 52-73.

Beyeza-Kashesya, J., S. Neema, A.M. Ekstrom, F. Kaharuza, F. Mirembe, and A. Kulane. 2010. "Not a Boy, Not a Child: A Qualitative Study on Young People's Views on Childbearing in Uganda." African Journal of Reproductive Health 14(1): 71-81.

Black, S.E., P.J. Devereux, and K.G. Salvanes. 2005. "The More the Merrier? The Effect of Family Size and Birth Order on Children's Education." The Quarterly Journal of Economics 120(2): 669-700.

Blackden, C.M., and Q. Wodon. 2006. "Gender, Time Use, and Poverty in Sub-Saharan Africa." World Bank Publication 7214, World Bank, Washington, DC.

Bongaarts, J. 2013. "The Implementation of Preferences for Male Offspring." Population and Development Review 39(2): 185-208.

Bound, J., D.A. Jaeger, and R.M. Baker. 1995. "Problems with Instrumental Variables Estimation When the Correlation between the Instruments and the Endogenous Explanatory Variable Is Weak." Journal of the American Statistical Association 90(430): 443-450.

Chen, L.C., E. Huq, and S. D'Souza. 1981. "Sex Bias in the Family Allocation of Food and Health Care in Rural Bangladesh." Population and Development Review 7(1): 55-70.

Chen, S.E., P. Bhagowalia, and G. Shively. 2011. "Input Choices in Agriculture: Is There a Gender Bias?" World Development 39(4): 561-568.

Clark, S. 2000. "Son Preference and Sex Composition of Children: Evidence from India." Demography 37(1): 95-108.

Conley, D. 2000. "Sibship Sex Composition: Effects on Educational Attainment." Social Science Research 29(3): 441-457.

Das, N. 1987. "Sex Preference and Fertility Behavior: A Study of Recent Indian Data." Demography 24(4): 517-530.

Das Gupta, M. 1987. "Selective Discrimination against Female Children in Rural Punjab, India." Population and Development Review 13(1): 77-100.

Davies, J.B., and J. Zhang. 1995. "Gender Bias, Investments in Children, and Bequests." International Economic Review 36(3): 795-818.

Deere, C.D. 1982. "The Division of Labor by Sex in Agriculture: A Peruvian Case Study." Economic Development and Cultural Change 30(4): 795-811. 
Deere, C.D., and M. Leon. 2003. "The Gender Asset Gap: Land in Latin America." World Development 31(6): 925-947.

Dercon, S. 1996. "Risk, Crop Choice, and Savings: Evidence from Tanzania." Economic Development and Cultural Change 44(3): 485-513.

Doss, C.R. 2002. "Men's Crops? Women's Crops? The Gender Patterns of Cropping in Ghana." World Development 30(11): 1987-2000.

Drèze, J., and M. Murthi. 2001. "Fertility, Education, and Development: Evidence from India." Population and Development Review 27(1): 33-63.

Eguavoen, A., S. Odiagbe, and G. Obetoh. 2007. "The Status of Women, Sex Preference, Decision-making, and Fertility Control in the Ekpoma Community of Nigeria." Journal of Social Science 15(1): 43-49.

Evers, B., and B. Walters. 2001. "The Model of a Gender-segregated Low-income Economy Reconsidered: Evidence from Uganda." Review of Development Economics 5(1): 76-88.

Feder, G. 1985. "The Relation between Farm Size and Farm Productivity: The Role of Family Labor, Supervision, and Credit Constraints." Journal of Development Economics 18(2/3): 297-313.

Food and Agriculture Organization. 2011. "The State of Food and Agriculture: Women in Agriculture - Closing the Gender Gap." Technical Report, FAO, Rome, Italy.

Gupta, N.D., and A. Dubey. 2006. "Fertility and the Household's Economic Status: A Natural Experiment using Indian Micro Data." Journal of Development Studies 42(1): 110-138.

Haggblade, S., and R. Dewina. 2010. "Staple Food Prices in Uganda." Food Security Collaborative Working Paper 58553, Department of Agricultural, Food, and Resource Economics, Michigan State University.

Hazarika, G. 2000. “Gender Differences in Children's Nutrition and Access to Health Care in Pakistan." Journal of Development Studies 37(1): 73-92.

Jacoby, H.G. 1991. "Productivity of Men and Women and the Sexual Division of Labor in Peasant Agriculture of the Peruvian Sierra." Journal of Development Economics 37(1/2): 265-287.

Jayachandran, S., and I. Kuziemko. 2011. "Why Do Mothers Breastfeed Girls Less Than Boys? Evidence and Implications for Child Health in India." The Quarterly Journal of Economics 126(3): 1485-1538.

Jha, P., M.A. Kesler, R. Kumar, F. Ram, U. Ram, L. Aleksandrowicz, D.G. Bassani, S. Chandra, and J.K. Banthia. 2011. "Trends in Selective Abortions of Girls in India: Analysis of Nationally Representative Birth Histories from 1990 to 2005 and Census Data from 1991 to 2011." The Lancet 377(9781): 1921-1928.

Kandiyoti, D. 1988. "Bargaining with Patriarchy." Gender and Society 2(3): 274-290.

Kilic, T., A. Palacios-López, and M. Goldstein. 2015. "Caught in a Productivity Trap: A Distributional Perspective on Gender Differences in Malawian Agriculture." World Development 70(C): 416-463.

Kim, J., and A. Aassve. 2006. "Fertility and Its Consequence on Family Labour Supply." IZA Discussion Paper 2162, Institute for the Study of Labor (IZA), Bonn, Germany.

Kim, J., H. Engelhardt, A. Prskawetz, and A. Aassve. 2009. "Does Fertility Decrease Household Consumption?” Demographic Research 20(26): 623-656.

Klasen, S., and S. Vollmer. 2013. “Missing Women: Age and Disease: A Correction.” Discussion Paper 133, Courant Research Centre: Poverty, Equity, and Growth, Goettingen, Germany.

Lanjouw, P., and M. Ravallion. 1995. "Poverty and Household Size." Economic Journal 105 (433): 1415-1434.

Lastarria-Cornhiel, S. 1997. "Impact of Privatization on Gender and Property Rights in Africa." World Development 25(8): 1317-1333.

Lloyd, C.B., C.E. Kaufman, and P. Hewett. 2000. "The Spread of Primary Schooling in SubSaharan Africa: Implications for Fertility Change." Population and Development Review 26(3): 483-515. 
Milazzo, A. 2014. "Son Preference, Fertility, and Family Structure: Evidence from Reproductive Behavior among Nigerian Women." Policy Research Working Paper 6869, World Bank, Washington, DC.

Newey, W.K. 1987. "Efficient Estimation of Limited Dependent Variable Models with Endogenous Explanatory Variables." Journal of Econometrics 36(3): 231-250.

Pande, R. 2003. "Selective Gender Differences in Childhood Nutrition and Immunization in Rural India: The Role of Siblings." Demography 40(3): 395-418.

Peterman, A., J. Behrman, and A. Quisumbing. 2014. "A Review of Empirical Evidence on Gender Differences in Nonland Agricultural Inputs, Technology, and Services in Developing Countries." In A.R. Quisumbing, R. Meinzen-Dick, T.L. Raney, A. Croppenstedt, J.A. Behrman, and A. Peterman, eds., Gender in Agriculture." New York, NY: Springer Netherlands.

Peterman, A., A. Quisumbing, J. Behrman, and E. Nkonya. 2011. "Understanding the Complexities Surrounding Gender Differences in Agricultural Productivity in Nigeria and Uganda." The Journal of Development Studies 47(10): 1482-1509.

Rosenzweig, M.R., and K.I. Wolpin. 1980a. "Life-cycle Labor Supply and Fertility: Causal Inferences from Household Models." Journal of Political Economy 88(2): 328-348.

- 1980b. "Testing the Quantity-Quality Fertility Model: The Use of Twins as a Natural Experiment." Econometrica 48(1): 227-240.

Sen, A. 1990. "More Than 100 Million Women Are Missing." The New York Review of Books, December 20. Available at www.nybooks.com/articles/1990/12/20/more-than-100million-women-are-missing.

Staiger, D., and J.H. Stock. 1997. “Instrumental Variables Regression with Weak Instruments.” Econometrica 65(3): 557-586.

Trussell, J., L. Martin, R. Feldman, J. Palmore, M. Concepcion, and D.A. Bakar. 1985. "Determinants of Birth-interval Length in the Philippines, Malaysia, and Indonesia: A Hazard-model Analysis." Demography 22(2): 145-168.

Udry, C. 1996. "Gender, Agricultural Production, and the Theory of the Household." Journal of Political Economy 104(5): 1010-1046.

Uganda Bureau of Statistics. 2012. "Uganda Demographic and Health Survey 2011." Technical Report, UBOS, Kampala, Uganda.

— 2014. "2014 Statistical Abstract." Technical Report, UBOS, Kampala, Uganda. Available at www.ubos.org/onlinefiles/uploads/ubos/statistical_abstracts/Statistical_Abstract_ 2014.pdf.

Van Campenhout, B. 2014. "Fertility, Agricultural Labor Supply, and Production: Instrumental Variable Evidence from Uganda." IFPRI Discussion Papers 1406, International Food Policy Research Institute (IFPRI).

Van der Stoep, G. 2008. “Childbearing and Labour Force Participation in South Africa: Sibling Composition as an Identification Strategy?" MPRA (Munich Personal RePEc Archive) paper, University Library of Munich, Germany.

Williamson, N.E. 1976. Sons and Daughters: A Cross-cultural Survey of Parental Preferences. Beverly Hills, CA: Sage. 